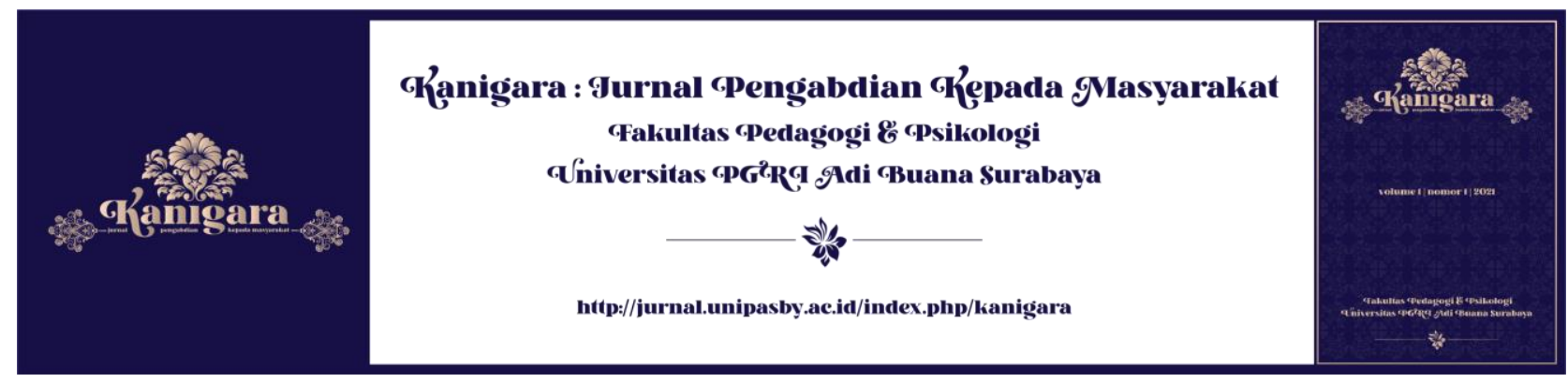

\title{
POWERPOINT SEBAGAI MEDIA PEMBELAJARAN DARING UNTUK KETERAMPILAN MENYIMAK SISWA USIA DINI
}

\author{
Armelia Nungki Nurbani ${ }^{1}$, Natalia Christina Sugiyanto ${ }^{2}$ \\ 1Program Studi Pendidikan Bahasa Inggris, Universitas PGRI Adi Buana Surabaya \\ 2Program Studi PG-PAUD, Universitas PGRI Adi Buana Surabaya \\ *Email: 1armelianungki@unipasby.ac.id
}

\begin{tabular}{l}
\hline Informasi Artikel \\
\hline Kata kunci: \\
Daring, Keterampilan \\
Menyimak, Power Point. \\
Diterima: 16-01-2021 \\
Disetujui: 23-01-2021 \\
Dipubikasikan: 26-01- \\
2021
\end{tabular}

Abstrak

PowerPoint adalah media yang bisa dimanfaatkan oleh guru PAUD dalam pembelajaran menyimak. Keterampilan menyimak sangat penting untuk anak usia dini karena keterampilan tersebutlah yang pertama kali muncul dan harus dikuasi. Tetapi faktanya guru PAUD di lingkungan KKN-PPM Kelurahan Wiyung-Surabaya belum paham benar pemanfaatan PowerPoint untuk keterampilan menyimak. Oleh karena itu, tujuan pengabdian masyarakat ini adalah supaya guru PAUD dapat memanfaatkan PowerPoint untuk pembelajaran menyimak. Metode penjelasan dan pendampingan dilakukan saat pelatihan. Metode penjelasan dilakukan dengan memberikan ceramah secara daring kepada guru PAUD. Sedangkan metode pendampingan dilakukan dengan memberikan arahan cara membuat materi atau kuis menggunakan PowerPoint untuk keterampilan menyimak. Penggunaan PowerPoint sebagai media pembelajaran keterampilan menyimak mempermudah guru PAUD untuk menyiapkan materi dan kuis. Dari hasil praktek, para guru PAUD telah berkontribusi untuk menjadikan pembelajaran menyimak daring yang mudah dan menyenangkan untuk siswa.

\footnotetext{
Abstact

PowerPoint is a medium that can be used by early childhood teachers in listening skill. Listening skill is very important for early childhood because they are the first to emerge and must be mastered. But the fact is that early childhood teachers in the community service of Wiyung-Surabaya do not really understand the use of Power Points for listening skills. Therefore, the purpose of this community service is that early childhood teachers can use PowerPoint for learning listening. Methods of explanation and mentoring were carried out during the training. The method of explanation is done by giving online lecture to early childhood teachers. While the mentoring method is carried out by providing directions on how to make material or quizzes using PowerPoint for listening skills. Using PowerPoints as a medium for learning listening skills makes it easier for early childhood teachers to prepare materials and quizzes. From the practical results, early childhood teachers have contributed to make online learning especially in listening skill easy and fun for students.
} 


\section{PENDAHULUAN}

Proses pembelajaran pada anak usia dini biasanya berlangsung dengan tatap muka pertemuan di ruang kelas. Hal ini dikarenakan ketika proses pembelajaran, anak-anak usia dini sangat membutuhkan bimbingandan arahan langsung dari guru, karena guru merupakan pelaksana dan pengajar proses pembelajaran di kelas (Larimore, 2020). Selain itu melalui pembelajaran langsung di kelas, guru dapat lebih mudah memberikan bimbingan kepada anak yang berhubungan langsung dengan berbagai kegiatan pembelajaran yang dilakukan, sehingga memudahkan anak untuk memahami bimbingan guru, sehingga dapat meningkatkan taraf perkembangannya. Pertumbuhan anak lebih ideal (Follari, 2015).

Pandemi Covid-19 memengaruhi semua kebiasaan dan aktivitas manusia, termasuk pengajaran. Guna mencegah penyebaran pandemi Covid-19, kegiatan edukasi tatap muka yang biasa berlangsung di dalam kelas kini dihentikan. Dengan menggunakan teknologi yang terkoneksi dengan internet, penghentian kegiatan belajar tatap muka secara langsung di kelas beralih ke pembelajaran berbasis daring (Kusmaharti, 2020). Pembelajaran daring ini berlaku untuk semua jenjang pendidikan termasuk sekolah PAUD. Lembaga pendidikan PAUD biasanya mengedepankan pembelajaran untuk merangsang perkembangan melalui bermain, dan pembelajaran di rumah dengan bantuan orang tua menggantikan sekolah PAUD. Pembelajaran daring didasarkan pada Surat Edaran No. 3 Tahun 2020 dan Surat Edaran No. 2 April 2020. Kedua kebijakan Menteri Pendidikan dan Kebudayaan tersebut terkait dengan kebijakan pencegahan penyebaran Covid-19 di satuan pendidikan dan penerapan kebijakan pendidikan pada masa darurat Covid-19. Kementerian Agama juga mengeluarkan kebijakan tentang mekanisme pembelajaran dan evaluasi penyakit gila pada masa darurat pandemi Covid-19 dengan menggunakan pembelajaran daring untuk mencegah pandemi Covid-19 sesuai nomor S-543 / Kk.22.12 / 1 / KS0.02 / 04/2020 dari surat terkait. Kerja kebijakan dan sistem pembelajaran.

Penyelenggaraan pembelajaran secara daring membutuhkan suatu media yang dapat menyebarkan pengetahuan atau menjadi wadah kegiatan pembelajaran. Media yang digunakan sebagai sarana pembelajaran daring ini menggunakan media internet yang dapat menyediakan fasilitas konektivitas di seluruh dunia. Internet yang tidak dibatasi oleh jarak dan waktu memungkinkan pembelajaran dapat dilakukan oleh siapapun, kapanpun dan dimanapun. Menggunakan internet sebagai alat pembelajaran dapat berdampak positif pada penggunaan internet, serta berperan sebagai pendidik diantara pengelolanya, sehingga kegiatan belajar dan mengajar sebagai ganti tatap muka langsung di kelas dapat terlaksana dengan efektif (Nugroho, 2012). Pembelajaran yang efektif mengacu pada pembelajaran yang 
dapat memanfaatkan penggunaan teknologi informasi dan komunikasi sebagai alat (Hanum, 2013). Akan tetapi, pemilihan media pembelajaran teknologi berbasis internet untuk anak usia dini harus cocok dan benar-benar diperhatikan, karena jika tidak sesuai dapat berdampak buruk pada anak. Menurut Putrawangsa dan Hasanah (2018) dan Rachmadtullah, dkk (2020), Efektivitas teknologi digital dalam proses pembelajaran salah satunya adalah pendidik mampu memahami prinsip dan faktor yang ada di dalamnya. Berbagai faktor juga harus diperhatikan ketika menggunakan teknologi dalam pembelajaran, yaitu jendela peluang penting pada anak usia dini (Ulfa, 2016).

Pengembangan dan pelatihan diri yang professional sangat dibutuhkan dalam pemanfaatan teknologi yang efektif dalam lingkungan pembelajaran PAUD. Pendidik pada sekolah PAUD harus memiliki pengetahuan yang luas agar tahu bagaimana menentukan cara yang tepat dalam menggunakan teknologi pembelajaran guna memenuhi kebutuhan belajar dan kognisi anak. Salah satu pembelajaran daring yang dapat diterapkan pada sekolah PAUD adalah konferensi video. Pembelajaran melalui konferensi video dapat menggantikan pembelajaran tatap muka yang biasa di kelas dengan kegiatan tatap muka virtual melalui aplikasi yang terhubung ke Internet. Menggunakan konferensi video dalam pembelajaran daring dapat membantu siswa dan pendidik untuk terus berinteraksi secara tatap muka meskipun mereka tidak dekat satu sama lain. Pembelajaran daring dapat mempersingkat waktu belajar, dan tentunya dapat menghemat biaya yang harus dikeluarkan lembaga pendidikan (Silahuddin, 2015). Dalam penelitian Luhulima et al., (2016) menunjukkan bahwa penggunaan media pembelajaran video sangat membantu proses pembelajaran pendidikan formal dan nonformal bagi anak-anak generasi Z (generasi yang lahir di era teknologi tinggi). Media pembelajaran yang digunakan dalam pembelajaran sangat serbaguna dan intuitif (Luhulima et al., 2016). Keberhasilan pembelajaran daring tidak hanya bergantung pada materi atau konten yang diberikan oleh pendidik, tetapi juga pada bagaimana proses pemberian materi dan media yang digunakan sehingga mempermudah siswa memahami materi yang diberikan.

Zoom Cloud Meeting adalah aplikasi yang dapat memberikan interaksi tatap muka untuk pendidik dan siswa melalui konferensi video dengan PC atau laptop atau smartphone, yaitu Zoom Cloud Meeting, yang menggabungkan konferensi video, obrolan, pertemuan online dan Kolaborasi seluler. Anda dapat mendownload aplikasi ini secara gratis dengan konsekuensi hanya 40 menit dlam satu kali tatap muka. Penggunaan konferensi dalam aplikasi ini sebenarnya dapat menampung 1000 peserta dalam satu konferensi. Fitur Zoom Cloud Meeting antara lain panggilan telepon, webinar, presentasi, dan banyak fitur lainnya. 
Untuk pendukung pembelajaran melalui Zoom Cloud Meeting, guru PAUD dapat menggunakan salah satu perangkat lunak yang tidak sulit untuk dioperasikan, yaitu PowerPoint. Dengan bantuan pembelajaran menggunakan PowerPoint, para guru dapat membuat kuis multi-pertanyaan dan membagikannya dengan anak anak. Guru juga tidak perlu menujukan lembar kerja bentuk kertas ke depan layar, guru hanya menunjukkan hasil digitalnya.

Tujuan dari KKN-PPM ini adalah menggunakan PowerPoint sebagai media pembelajaran menyimak dengan aplikasi Zoom untuk membantu guru-guru PAUD di Wilayah Wiyung-Surabaya membuat sebuah pembelajaran daring yang mudah dan menyenangkan bagi siswa. Media menjadi konsentrasi utama dalam pelatihan ini karena guru-guru anak usia dini masih kesulitan dalam penerapan media yang cocok. Media PowerPoint diangkat karena merupakan perangkat lunak yang sangat dekat, mudah, dan bisa digunakan oleh guru-guru PAUD, tetapi faktanya masih banyak guru-guru PAUD di lingkungan Wiyung-Surabaya terkendala dengan penggunaan PowerPoint khususnya untuk keterampilan menyimak. Fakta ini didukung oleh hasil identifikasi permasalahan yang terjadi pada guru-guru sekolah anak usia dini yaitu:

\section{Diagram 1. Permasalahan}

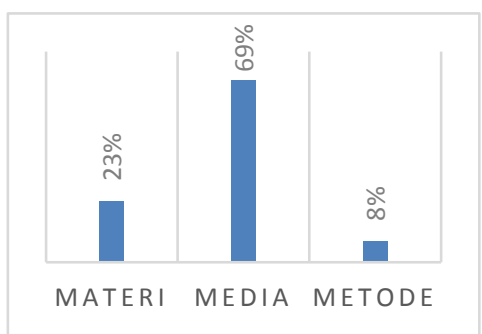

Diagram 2. Keterampilan yang masih sulit diterapkan

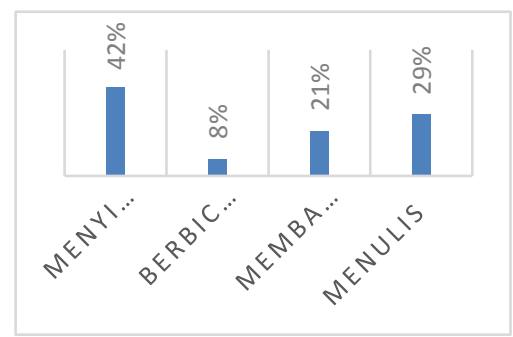

Berdasarkan uraian di atas, penyelenggaraan kegiatan pelatihan cara membuat kuis melalui PowerPoint dalam pembelajaran untuk anak usia dini sangat penting. Kegiatan pelatihan dibatasi bagi guru-guru sekolah pada anak usia dini dan hanya difokuskan pada peningkatan kemampuan guru-guru dalam memanfaatkan cara pembuatan pembelajaran/kuis menggunakan PowerPoint dalam keterampilan menyimak sehingga guru menjadi lebih aktif dan produktif dalam menghasilkan pembelajaran/kuis yang menarik melalui PowerPoint.

\section{METODE}

Kegiatan pelatihan dari awal hingga akhir benar-benar memanfaatkan PowerPoint untuk keterampilan menyimak anak usia dini dan sedikit tambahan pengoperasian Zoom Cloud Meeting sehingga guru dapat langsung menerapkannya pada anak usia dini yang 
mereka ajarkan di sekolah di masa mendatang. Sasaran pelatihan adalah para guru Anak Usia Dini lingkungan KKN-PPM di Kelurahan Wiyung-Surabaya yang berjumlah 10 guru baik tingkat PG maupun TK.

Dalam pelatihan ini, guru-guru PAUD diajarkan bagaimana pemanfaatan PowerPoint sebagai pembelajaran daring dalam keterampilan menyimak. Metode yang digunakan dalam pengabdian masyarakat ini adalah metode eksplanatori atau penjelasan dan pendampingan selama pelatihan dengan metode pelatihan daring menggunakan Zoom Cloud Meeting. Metode eksplanatori atau penjelasan dilakukan dengan memberikan informasi berupa ceramah kepada guru PAUD di lingkungan KKN-PPM Kelurahan Wiyung-Surabaya. Dilanjutkan dengan pendampingan sebagai tindak lanjut. Dengan memberikan panduan rinci tentang pembuatan dan pengoperasian PowerPoint, ini digunakan sebagai metode pelatihan lanjutan dan sebagai alat pembelajaran.

Dalam rangkaian kegiatan pelatihan, yang pertama yaitu penjelasan kepada guruguru PAUD dimana mereka disuguhkan berbagai macam informasi mengenai pentingnya keterampilan menyimak pada anak usia dini, bagaimana cara membuat materi atau kuis untuk keterampilan menyimak dengan PowerPoint, bagaimana pentingnya pembelajaran tatap muka secara daring dengan siswa melalui Zoom Cloud Meeting. Kedua, pendampingan kepada guru-guru PAUD sebagai tindak lanjut untuk membuat kuis dalam keterampilan menyimak di PowerPoint. Ketiga, pendampingan tindak lanjut pengoperasian Zoom Cloud Meeting.

\section{HASIL DAN PEMBAHASAN}

\section{A. Keterampilan Menyimak}

Keterampilan menyimak pada anak usia dini itu penting dan tidak bisa dianggap remeh. Melalui menyimak, anak akan mulai belajar dan terlatih untuk menguasai bahasa. Ketika anak memiliki kemampuan menyimak yang baik, anak tersebut dapat dengan mudah melaksanakan instruksi atau pesan yang didengar atau dikomunikasikan kepadanya. Oleh karena itu kita dapat memahami bahwa yang akan kita perhatikan adalah metode yang akan kita terapkan pada PAUD, dan memang kita harus memperhatikan dan memilih metode yang menyenangkan dan menarik agar anak memiliki kemampuan menyimak yang baik. Peningkatan kemampuan berbahasa dilakukan dengan cara-cara yang menarik bagi anak agar anak dapat mendengarkan guru dengan baik. (Budyawati, Luh Putu Indah Hartanto, Wiwin, 2017).

Dengan pertimbangan di atas, penggunaan media PowerPoint yang tepat menjadi hal 
penting dalam pengajaran keterampilan menyimak. Hal ini tentu sesuai dengan PowerPoint yang memenuhi kriteria tersebut. PowerPoint adalah aplikasi Microsoft Office yang dapat digunakan sebagai media presentasi dan kuis yang menggunakan hyperlink dengan menggunakan beberapa slide. Untuk keterampilan menyimak, guru dapat menambahkan audio yang bisa didapat dari berbagai sumber.

\section{B. Power Point sebagai Media Pembelajaran Menyimak}

Segala aspek dalam menstimulasi tumbuh kembang anak usia dini sangat erat kaitannya dengan media pembelajaran. Sangat erat kaitannya dikarenakan pembelajaran anak usia dini dilakukan dengan menggunakan media pembelajaran yang nyata. Dengan media pembelajaran yang nyata tersebut anak dapat beroperasi secara aktif (Zaini \& Dewi, 2017). PowerPoint sebagai media pembelajaran bukan lagi suatu hal baru dalam dunia pendidikan. Di era tatanan baru ini, pembelajaran daring harus dilakukan oleh semua jenjang Pendidikan. Oleh sebab itu, tidak heran jika banyak guru-guru yang menjadikan PowerPoint sebagai media pembelajaran mereka karena dinilai cukup mudah untuk dioperasikan. Tetapi masih banyak guru-guru khususnya untuk anak usia dini belum paham betul penggunaan PowerPoint untuk melatih keterampilan menyimak siswa. Pemanfaatan PowerPoint untuk media pembelajaran keterampilan menyimak yang bisa digunakan oleh guru sekolah anak usia dini dikarenakan lebih sederhana dan mudah di akses oleh guru-guru. Oleh karena itu diharapkan pelatihan akan membantu para guru yang menggunakan PowerPoint lebih mudah membuatnya dan memahami.

\section{Membubuhkan gambar}

Sebagai contoh untuk kegiatan keterampilan menyimak, materi berikut adalah tentang bunyi hewan. Adapun langkah-langkah pembubuhan gambar hewan pada PowerPoint dijelaskan sebagai berikut:

1) Membuka Aplikasi Power Point

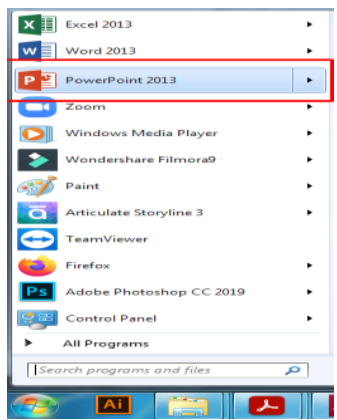

2) Pilih Blank Presentation

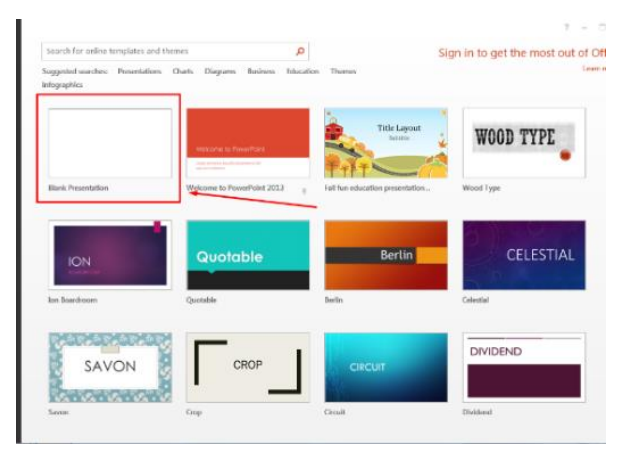


3) Ketik Judul pembelajaran yang akan diajarkan

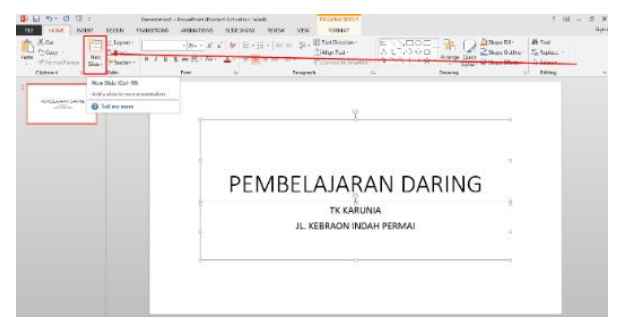

4) Buka Google, klik di bagian gambar dan ketik di kotak pencarian "hewan anjing"

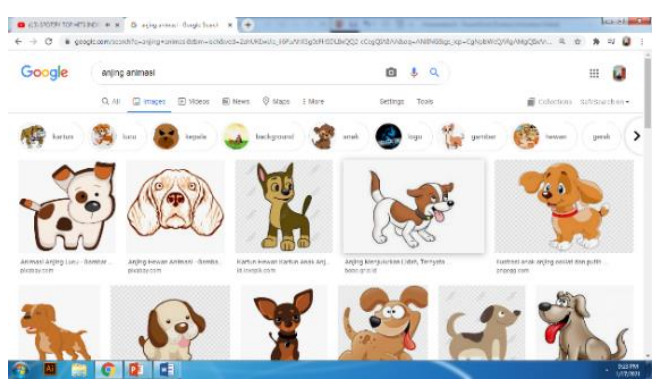

5) Klik kanan dan pilih copy image

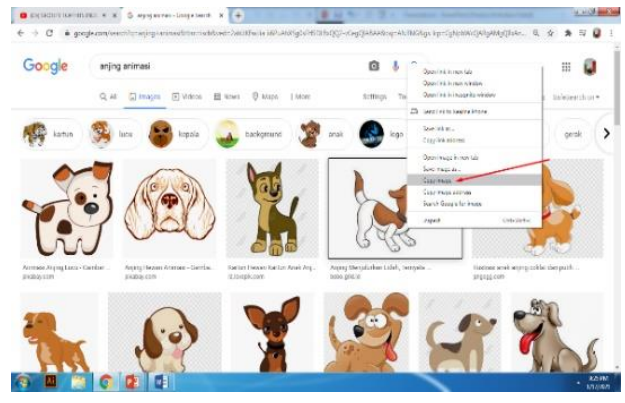

6) klik "paste" pada PowerPoint untuk memunculkan gambar. Ulangi cara ke 4 dan 5 untuk hewan selanjutnya

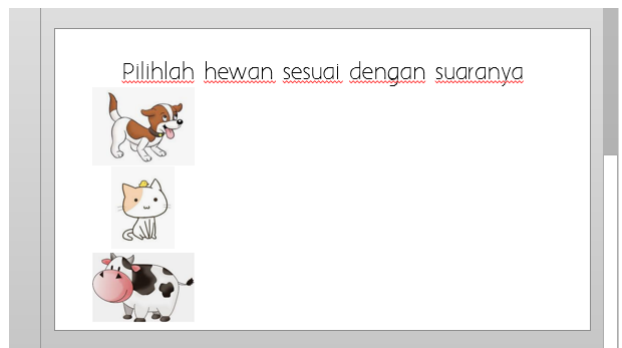

\section{Menambahkan suara}

Adapun langkah-langkah penambahan suara hewan pada PowerPoint dijelaskan sebagai berikut:

1) Cari audio di website

https://ytmp3.cc/en13/

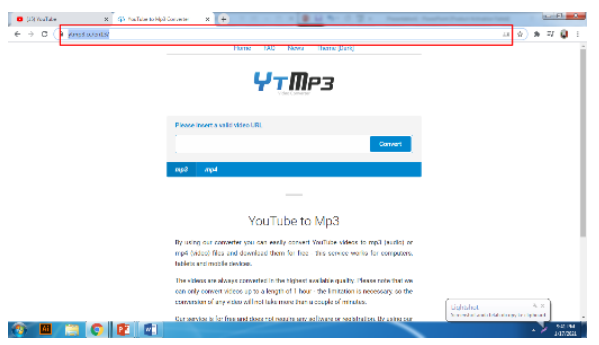

2) Buka website

https://www.youtube.com untuk mencari suara "anjing" suara hewan yang di butuhkan, lalu copy link di atas

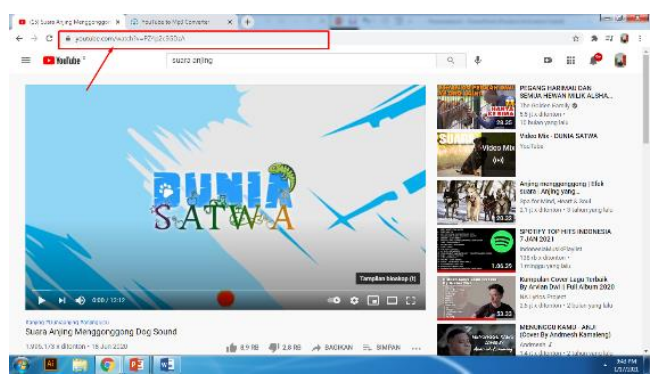


3) Jika sudah di copy kita berpindah di link https://ytmp3.cc/en13 lalu copy ke dalam kolom yang ada di bawah dan format download di ganti menjadi mp3 setelah itu klik "convert"

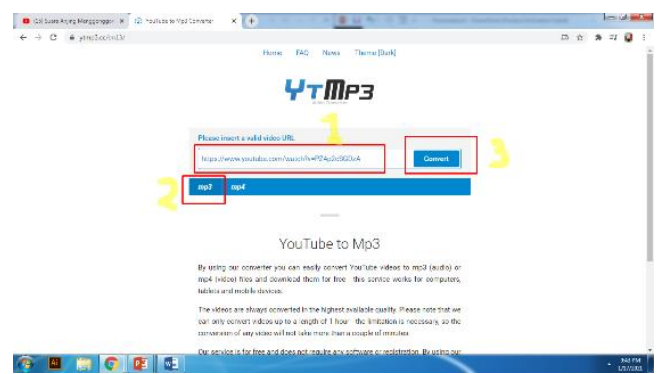

4) Tunggu 5 detik, klik "download". Lakukan cara ke 1-4 secara berulang untuk mendownload suara-suara yang di butuhkan

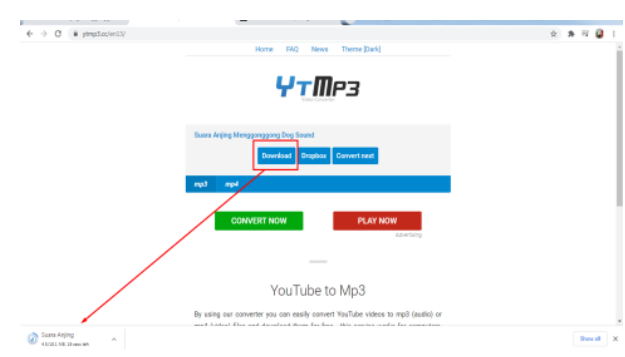

5) Kembali ke PowerPoint untuk menambahkan audio yang sudah di download. Klik shape yang akan di pasangkan sesuai dengan suara hewannya. Klik kanan pada tulisan bunyi hewan tersebut, lalu pilih "insert" lalu klik "audio"dan pilih "audio on pc"

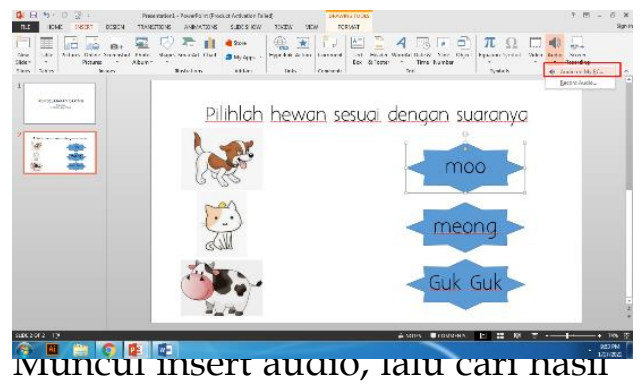

6) suara yang sudah di download, jika sudah di klik 1x, lalu klik "insert"

7)

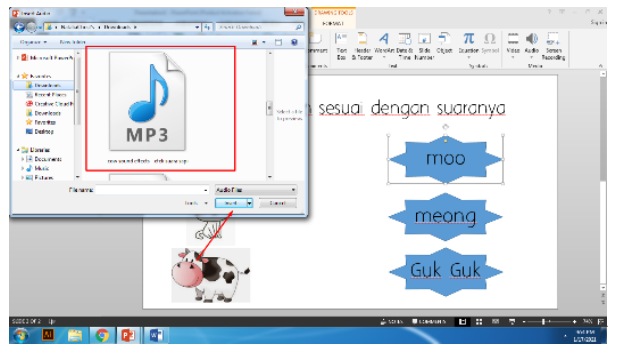

dengan audio yang di butuhkan

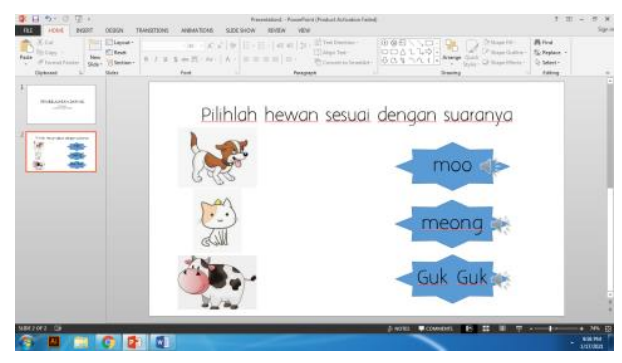

8) buat shape berbentuk petunjuk di menu "insert" lalu klik "shape": pilih gambar panah lalu letakkan sesuai dengan gambar ke suara

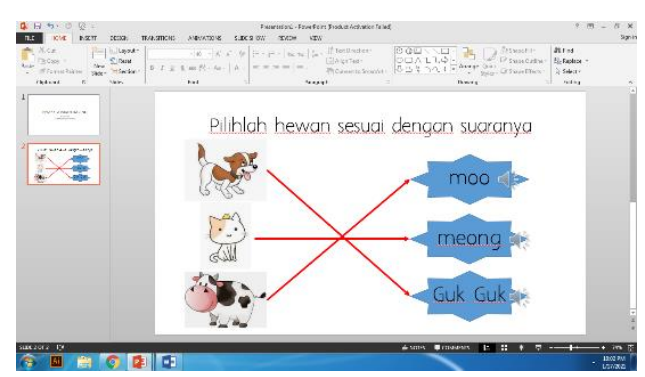




\section{Share screen pada Zoom Cloud Meeting}

Berikut adalah tahapan-tahapan bagaimana cara memulai kelas untuk keterampilan menyimak siswa PAUD dengan menggunakan Zoom Cloud Meeting:

1) Buka terlebih dahulu aplikasi zoom lalu klik share screen pada layer.

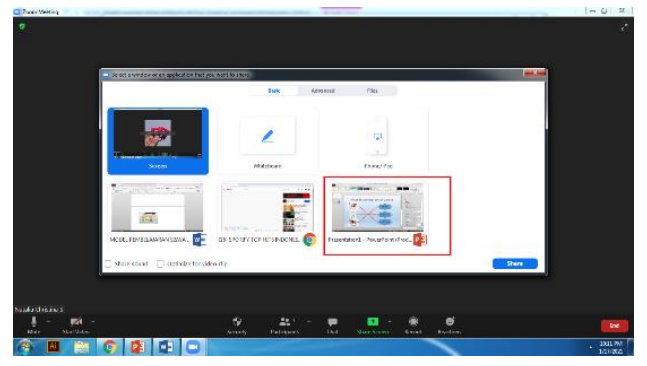

2) Ini adalah tampilan pada saat share screen, Untuk menampilkan kita hanya perlu klik f5 untuk keluar kita klik esc.

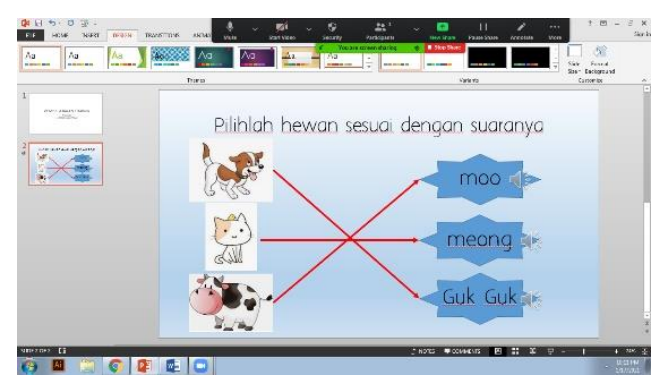

\section{Pendampingan}

Tahap pendampingan ini merupakan tahap yang penting dan menentukan dalam keberhasilan pembuatan dan penggunaan PowerPoint serta pengaplikasian Zoom Cloud Meeting untuk menampilkan PowerPoint pada kelas daring. Sebagaimana konsep awal bahwa kegiatan ini bersifat pendampingan kepada 10 guru-guru PAUD di sekitar lingkungan KKN Kelurahan Wiyung-Surabaya, maka melalui pendampingan tersebut para guru bisa membuat PowerPoint sebagai media pembelajaran keterampilan menyimak siswa PAUD yang mudah dioperasikan. Oleh karena itu beberapa aspek pendampingan yang dilakukan meliputi (1) pembuatan media Zoom Cloud Meeting sebagai wadah komunikasi dengan para guru pasca pelatihan secara daring; (2) pemberian konsultasi kepada guru yang membuat PowerPoint baik bertemu di Zoom Cloud Meeting maupun melalui WhatsApp group; serta (3) pendampingan konsultasi kepada guru saat mereka menghadapi kendala baik pada saat pembuatan PowerPoint maupun operasional Zoom Cloud Meeting tersebut dalam kegiatan pembelajaran. 
Hasil dari pendampingan ini adalah, guru-guru PAUD yang mengikuti pelatihan mengirimkan hasil akhir PowerPoint yang mereka buat melalui WhatsApp group yang telah dibuat sebelumnya dengan bermacam-macam topik yang berbeda setiap guru. Tentunya semua topik yang dibuat mengenai kegiatan keterampilan menyimak siswa PAUD. Setelah diteliti, semua guru berhasil membuat kuis keterampilan menyimak dengan PowerPoint, meskipun ada 3 guru yang masih belum rapi dalam penataan.

\section{KESIMPULAN}

Sebagai salah satu media, PowerPoint memberikan tidak hanya kemudahan pengoperasian untuk para guru PAUD melainkan juga sebagai sarana pembelajaran yang menyenangkan untuk Anak Usia Dini khususnya untuk peningkatan keahlian menyimak karena guru bisa memberikan gambar-gambar yang menarik beserta suara-suara yang bisa dimasukkan. PowerPoint adalah media dasar yang sangat bermanfaat untuk guru PAUD karena memberikan berbagai fitur yang sangat sesuai dan mendukung jalannya pembelajaran kemampuan menyimak seperti yakni menyediakan sarana pembuatan bentuk, teks dan gambar, serta yang paling penting adalah audio. Dengan adanya pelatihan dan pendampingan ini, guru-guru PAUD lebih termotivasi untuk membuat pembelajaran keterampilan menyimak menjadi lebih bervariasi.

\section{DAFTAR PUSTAKA}

Budyawati, L. P. I., \& Hartanto, W. (2017). Implementasi Metode Bermain Peran Untuk Peningkatan Kemampuan Menyimak Anak Usia Dini Di Paud Sekarwangi Desa Bangorejo Banyuwangi 2017. JURNAL PENDIDIKAN EKONOMI: Jurnal Ilmiah Ilmu Pendidikan, Ilmu Ekonomi Dan Ilmu Sosial, 11(2), 24. https://doi.org/10.19184/jpe.v11i2.6331

Follari, L. (2015). Foundations and Best Practices in Early Childhood Education: History, Theories, and Approaches to Learning (3rd Edition). Australia: Pearson Higher Education AU.

Hanum, N. S. (2013). Keefetifan e-learning sebagai media pembelajaran (studi evaluasi model pembelajaran e-learning SMK Telkom Sandhy Putra Purwokerto). Jurnal Pendidikan Vokasi, 3(1), 90-102. https://doi.org/10.21831/jpv.v3i1.1584

Kusmaharti, D. (2020). Efektivitas Online Learning terhadap Kemampuan Pemecahan Masalah Matematika Mahasiswa. Journal of Medives: Journal of Mathematics Education IKIP Veteran Semarang, 4(2), 311-318. https:// doi.org/10.31331/medivesveteran.v4i2.1199

Larimore, R. A. (2020). Preschool Science Education: A Vision for the Future. Early Childhood Education Journal, 0123456789. https:// doi.org/10.1007/s10643-020-01033-9

Luhulima, D. A., Degeng, I. N. S., \& Ulfa, S. (2016). Pembelajaran Berbasis Video Untuk Anak Generasi Z. Universitas Mercubuana.

Nugroho, P. D. (2020, Maret 26). PDP Virus Corona di Kudus Bertambah Lagi Jadi 22 Orang. 
Dipetik Maret 27, 2020, dari Kompas.com: https://regional.kompas.com/read/2020/03/26/19125571/pdp-virus-corona-dikudus-bertambah-lagi-jadi-22-orang?page=all\#page3

Putrawangsa, S., Hasanah, U. (2018). Integrasi Teknologi Digital dalam Pembelajaran di Era Industri 4.0. Jurnal Tastqif. 16(1), 42-54. Retrieved from http://journal.uinmataram.ac.id/index.php/tatsqif/article/view/203

Rachmadtullah, R., Yustitia, V., Setiawan, B., Fanny, A. M., Pramulia, P., Susiloningsih, W., ... \& Ardhian, T. (2020). The Challenge Of Elementary School Teachers To Encounter Superior Generation In The 4.0 Industrial Revolution: Study Literature. International Journal of Scientific \& Technology Research, 9(4), 1879-82.

Silahuddin, S. (2015). Penerapan E-Learning dalam Inovasi Pendidikan. CIRCUIT: Jurnal Ilmiah Pendidikan Teknik Elektro, 1(1), 48-59. https://doi.org/10.22373/crc.v1i1.310

Surat Edaran Menteri Pendidikan dan Kebudayaan (Mendikbud) Republik Indonesia No. 4 Tahun 2020 tentang Pelakasanaan Kebijakan Pendidikan dalam Masa Darurat Penyebaran Covid-19. http://pgdikmen.kemdikbud.go.id/read-news/surat-edaranmendikbud-nomor-4-tahun-2020

Ulfa, S. (2016). Pemanfaatan Teknologi Bergerak sebagai Media Pembelajaran bagi Anak Usia Dini. Edcomtech, 1, 1-8.

Zaini, H., \& Dewi, K. (2017). Pentingnya Media Pembelajaran Untuk Anak Usia Dini. Raudhatul Athfal: Jurnal Pendidikan Islam Anak Usia Dini, 1(1), 81-96. https://doi.org/10.19109/ra.v1i1.1489 